\title{
Evaluasi Pelayanan Kesehatan Jiwa Berbasis Komunitas Di Kota Palembang
}

\author{
Ririn Noviyanti Putri ${ }^{1}$, Haerawati Idris ${ }^{2}$, Nur Alam Fajar ${ }^{3}$ \\ ${ }_{1,2,3}$ Universitas Sriwijaya \\ Correspondence email: ririnnoviyanti95@gmail.com
}

\begin{abstract}
Abstrak. Konsep upaya kesehatan jiwa paripurna merupakan penanganan masalah kesehatan serta landasannya mencakup upaya kesehatan jiwa masyarakat, didukung pelayanan kesehatan jiwa dasar dan diperkuat pelayanan kesehatan jiwa rujukan yang terintegrasi. Sebagian besar ODGJ belum mendapatkan pelayanan kesehatan. Belum optimalnya pelayanan kesehatan jiwa secara tidak langsung memengaruhi tingkat keberhasilan pembangunan kesehatan. Penelitian ini bertujuan menganalisis pelaksanaan pelayanan kesehatan jiwa berbasis komunitas di Kota Palembang. Metode penelitian dengan desain kualitatif, informan dalam penelitian dipilih secara purposive. Teknik pengambilan data dengan wawancara mendalam kepada 12 informan, observasi dan telaah dokumen. Triangulasi yang dilakukan berupa triangulasi sumber, metode dan data. Hasil penelitian menunjukkan bahwa kesadaran masyarakat mengenai kesehatan jiwa masih rendah karena masih tingginya stigma negatif masyarakat dan minimnya pengetahuan masyarakat yang dapat berdampak pada dukungan yang akan diberikan oleh keluarga. Maka diperlukannya pemberdayaan masyarakat dalam menjangkau masyarakat untuk dapat mengakses pelayanan kesehatan jiwa. Penelitian ini menyarankan agar adanya sikap proaktif dari Puskesmas untuk menjangkau masyarakat di seluruh wilayah kerjanya dengan cara memperbanyak kegiatan di luar Puskesmas, memperkuat kerja sama lintas sektor dan pemberdayaan masyarakat.
\end{abstract}

Kata kunci: Evaluasi; Pelayanan Kesehatan Jiwa; Puskesmas

\begin{abstract}
The concept of complete mental health efforts is the handling of health problems and its foundation includes community mental health efforts, supported by basic mental health services and strengthened integrated referral mental health services. Most of ODGJ have not gotten health care. Not yet optimal mental health services indirectly affect the success rate of health development. This research aims to analyse the implementation of community-based mental health services in Palembang. Methods of research with qualitative design, informant in the research is chosen purposive. Data retrieval techniques with indepth interviews to 12 informant, observation and study of documents. Triangulation is done in the form of triangulation of source, method and data. Results showed that the low public awareness of mental health is still low because of the high level of negative stigma of society and low public knowledge that can impact on the support that will be provided by Family. So the empowerment of community needs to reach people to access mental health services. This research suggests that there is a proactive stance from the public health center to reach people throughout their workforce by reproducing activities outside the public health center, strengthening cross-sector cooperation and empowering community.
\end{abstract}

Keywords: Evaluation; Mental Health Services; Public Health Center

\section{PENDAHULUAN}

Konsep upaya kesehatan jiwa paripurna merupakan penanganan masalah kesehatan serta landasannya mencakup upaya kesehatan jiwa masyarakat, didukung pelayanan kesehatan jiwa dasar dan diperkuat pelayanan kesehatan jiwa rujukan yang terintegrasi (Kemenkes, 2015). Integrasi layanan kesehatan jiwa dalam pengaturan komunitas dan layanan kesehatan telah disarankan sebagai strategi untuk mengurangi kesenjangan perawatan (Keynejad RC et al, 2017).

Paket perawatan tingkat komunitas (masyarakat) ini bertujuan untuk meningkatkan akses masyarakat terhadap perawatan dan memberikan kontribusi dalam meningkatkan hasil dan inklusi sosial orang dengan masalah kesehatan jiwa, serta untuk mengubah pandangan/persepsi masyarakat terkait kesehatan jiwa agar berkurangnya stigma kesehatan jiwa yang negative dai kalangan masyarakat. Upaya pemberdayaan masyarakat terhadap kesehatan jiwa dapat dicapai dengan manajemen pelayanan kesehatan khususnya pelayanan kesehatan jiwa berbasis komunitas (Rosiana et al, 2016). Pelayanan kesehatan jiwa komunitas ini dapat dilihat pada lingkungan masyarakat pengguna dan puskesmas (Jordans MJD et al, 2019).

Berdasarkan hasil Riset Kesehatan dasar (2018), proporsi gangguan jiwa pada tahun 2013 di Sumatera Selatan meningkat dari 1,1 mil per 1.000 penduduk menjadi 8 mil per 1.000 penduduk pada tahun 2018 . Diketahui jumlah kunjungan gangguan jiwa sekitar 53.655 orang dan tahun 2018 meningkat menjadi 56.389 orang. Jumlah kunjungan gangguan jiwa pada Puskesmas Kota Palembang tahun 2017 sebanyak 8.506 jiwa dan pada tahun 2018 menjadi 10.623 jiwa. Hal ini diperkuat dengan data Dinsos Kota Palembang, terdapat peningkatan penjangkauan ODGJ dari tahun 2017 yaitu 81 orang dan pada tahun 2018 meningkat sebesar 212 orang (Dinas Kesehatan Kota Palembang, 2017).

Berdasarkan hasil survey awal yang dilakukan oleh peneliti, di Kota Palembang hanya terdapat 2 
puskesmas yang memiliki posyandu kesehatan jiwa dan pemberdayaan masyarakat, yaitu Puskesmas 1 Ulu dan Puskesmas Kenten. Inovasi posyandu jiwa tersebut baru dilaksanakan pada tahun 2018 lalu, sedangkan Puskesmas Kenten baru melaksanakan pada tahun 2019. Persentase kunjungan gangguan jiwa di Puskesmas 1 Ulu pada tahun 2017 sebesar 119 jiwa. Pada tahun 2018 meningkat menjadi 259 jiwa. Inovasi tersebut berdampak positif dikarenakan cakupan pelayanan kesehatan jiwa di puskesmas tersebut pada tahun 2018 sebesar 93,75\% dan tahun 2019 meningkat menjadi 103,93\% (Dinas Kesehatan Kota Palembang, 2017).

Jumlah kasus kesehatan jiwa yang terus meningkat dan bermacam-macam tantagan yang telag dihadapi menjadikan perubahan fundamental terhadap. Perubahan tersebut yaitu dari pelayanan kesehatan jiwa dengan perawatan yang tertutup berubah menjadi perawatan yang terbuka. Sedangkan dari sisi penanganannya dari pendekatan klinis-individual berubah menjadi produktif-sosial dikarenakan berkembangnya konsep kesehatan jiwa komunitas yang melibatkan secara aktif seluruh potensi yang ada dimasyarakat. Sebagai layanan kesehatan dasar, puskesmas harus memberikan pelayanan yang optimal serta kemudahan bagi masyarakat dalam mengakses pelayanan tersebut. Hal tersebut jika diterapkan dengan baik, dapat meningkatkan hasil kegiatan program pelayanan kesehatan jiwa. Berdasarkan latar belakang tersebut, maka perlu evaluasi lebih lanjut mengenai Pelayanan Kesehatan Jiwa Berbasis Komunitas di Kota Palembang.

\section{METODE}

Penelitian ini menggunakan desain riset kualitatif. Pendekatan yang digunakan dalam penelitian adalah fenomena deskriptif. Penelitian kualitatif ini mengamati kegiatan program pelayanan kesehatan jiwa berbasis komunitas di wilayah kerja Puskesmas 1 Ulu dan Pkm Kenten Kota Palembang. Pemilihan lokasi Pkm 1 Ulu dan Pkm Kenten yaitu berdasarkan puskesmas yang memiliki posyandu jiwa, terdapat pemberdayaan masyarakat (kader) dan peningkatan jumlah kunjungan orang dengan gangguan jiwa pada puskesmas tersebut.

Penentuan informan dilakukan dengan menggunakan teknik purposive sampling. Partisipan pada penelitian ini berjumlah 12 partisipan dengan mempertimbanglan saturasi data. Informan pada penelitian ini antara lain keluarga pasien, kader, pengeloloa program puskesmas, dokter, perawat dan pengelola program kesehatan jiwa di Dinas Kesehatan. Cara pengumpulan data dilakukan dengan wawancara mendalam, observasi dan telaah dokumen. Adapun triangulasi yang dilakukan dalam penelitian ini adalah triangulasi sumber, metode dan data. Analisis data yang digunakan adalah content analysis.

\section{HASIL DAN PEMBAHASAN \\ Kesadaran Masyarakat}

Tabel 1. Analisis Tema Kesadaran Masyarakat tentang Gangguan Jiwa

\begin{tabular}{lll}
\hline \multicolumn{1}{c}{ Tema } & \multicolumn{1}{c}{ Kategori } & \multicolumn{1}{c}{ Sub Kategori } \\
\hline Kurangnya & Pengetahuan & Tidak mengerti arti \\
Kesadaran & Masyarakat & gangguan jiwa \\
Masyarakat & Rendah & Tidak mengerti cara \\
& & merawat pasien \\
& & ODGJ \\
& Stigma & Malu \\
& Masyarakat & Mengurung \\
& Negatif & Mempasung \\
\hline
\end{tabular}

\section{Pengetahuan}

Pada lingkungan masyarakat, telah banyak beredar kepercayaan atau mitos yang salah mengenai kesehatan jiwa, ada yang percaya bahwa penyakit jiwa disebabkan oleh gangguan roh jahat, ada yang menuduh bahwa itu akibat guna-guna dan lain-lainnya. Kepercayaan yang salah ini hanya akan merugikan penderita dan keluarganya karena orang dengan gangguan jiwa tersebut tidak mendapat pengobatan secara cepat dan tepat. Pertolongan pertama yang diberikan oleh keluarga ketika mengetahui ada yang mengalami gangguan jiwa maka mereka berspekulasi dalam mencari pengobatan.

Hasil wawancara dengan Keluarga:

"dio ni keno taunyo sudah ngamuk-ngamuk itu, jadi dio ni ibuk kurung dikamar...pernah dibawak ke orang pintar disuruh minum dogan tapi katek hasil" (AS).

Hasil tersebut juga didukung oleh hasil wawancara dengan pihak Dinas Kesehatan:

"masyarakat itu pengetahuannya masih rendah, mereka masih anggap gangguan jiwa ini sebagai hal yang tabu, penyakit yang memalukan, tidak bisa disembuhkan, sehingga banyak keluarga itu yang mengurung, mempasung yang dapat membuat keterlambatan dalam pengobatan ODGJ tersebut."(DS).

Berdasarkan hasil penelitian menunjukkan bahwa keluarga ODGJ membawa pasien berobat pertama bukan ke pelayanan kesehatan tetapi ke pengobatan alternatif lain seperti dukun, ustad, kiai dan lainnya. Hal tersebut terjadi dikarenakan masih tingginya kepercayaan supratural yang ada di masyarakat mengenai kesehatan jiwa dan rendahnya pengetahuan masyarakat yang dapat mempengaruhi pencarian pengobatan terhadap ODGJ.

Hasil observasi menunjukkan bahwa tidak adanya media promosi kesehatan mengenai kesehatan jiwa yang diberikan oleh puskesmas itu sendiri seperti brosur ataupun leaflet bahkan poster yang ditempel di tembok. Rendahnya pengetahuan keluarga mengakibatkan kesalahan dalam menangani pasien ODGJ seperti mengurung dan mempasung pasien. Selain itu, dukungan yang buruk dalam merawat pasien juga dapat dipengaruhi oleh faktor tingkat pendidikan, lama sakit 
dan pendapatan keluarga. Peningkatan pengetahuan keluarga dapat dilakukan dengan memberikan pendidikan kesehatan atau edukasi kepada keluarga tentang gangguan jiwa.

Pengetahuan masyarakat dan keluarga yang rendah dalam kesehatan jiwa ini merupakan salah satu kendala dalam proses penyembuhan ODGJ. Persepsi keluarga dan masyarakat selama ini yaitu penyakit kesehatan jiwa merupaka sebuah aib. Masyarakat dan keluarga masih percaya terhadap kepercayaan supranatural yang mana kesehatan jiwa diakibatkan oleh guna-guna, santet, kutukan dan lainnya. Akibat dari dampak tersebut, pasien ODGJ mengalami keterlambatan dalam pengobatan dikarenakan keluarga lebih memilih membawa pasien untuk berobat ke dukun maupun ke paranormal (Hawari \& Dadang, 2011).

Hal tersebut sejalan dengan hasil penelitian menunjukkan bahwa $80 \%$ keluarga membawa pasien ODGJ pertama kali untuk mendapatkan pengobatan ke dukun maupun orang pintar. Kondisi ini diperberat dengan sikap keluarga yang cenderung memperlakukan pasien dengan cara disembunyikan, diisolasi, dikucilkan, bahkan ada yang sampai dipasung. Hasil penelitian menunjukkan bahwa $80 \%$ pasien pernah dipasung sebelum memanfaatkan pelayanan kesehatan di puskesmas.

Penelitian yang dilakukan oleh Keliat et al (2012) menunjukkan bahwa rendahnya pengetahuan keluarga mengakibatkan $64 \%$ penderita gangguan jiwa dibawa ke paranormal atau orang pintar. Pasien akan dibawa ke pelayanan kesehatan apabila pasien tersebut sudah kronis (Subandi, 2012). Upaya pengobatan kepada orang drngn gangguan jiwa yang membutuhkan waktu yang relative lama dan akses ke pelayanan kesehatan jiwa yang juga jauh akan menambah beban biaya pengobatan bagi keluarga. Sehingga menyebabkan keluarga untuk mengambil tindakan penanganan dengan caranya sendiri seperti melakukan pemasungan terhadap ODGJ tersebut (Suswinarto DY, 2015).

Dukungan keluarga dalam merawat pasien gangguan jiwa salah satu yang mempengaruhinya adalah tingkat pendidikan keluarga. Hasil penelitian menunjukkan bahwa (48\%) tingkat pendidikan keluarga adalah SD. Status tingkat pendidikan yang rendah kurang memiliki informasi yang cukup terkait dengan pengatahuan penyakit dan perawatannya dalam memberikan dukunga (WHO, 2011). Selain pegetahuan, faktor keyakinan dan budaya juga dapt mempengaruhi keluarga dalam pencarian pengobatan. Faktor dari keyakinan dan budaya yang diyakini oleh masyarakat menganggap penyebab gangguan jiwa dikarenakan oleh roh jahat (Ching Wu.H, Chen.F, 2016).

Dukungan buruk yang diberikan keluarga terhadap pengobatn pasien dengan gangguan jiwa yaitu dikarenakan oleh pengetahuan yang rendah serta masih tingginya kepercayaan supranatural di masyarakat. Salah satu bentuk dukungan yang buruk diberikan oleh kerluarga yaitu dengan tindakan pemasungan maupun pengurungan pasien. Hal tersebut merupakan pelanggaran hak asasi manusia yang akan memperparah keadaan pasien itu sendiri (Tristiana et al, 2018). Penelitian ini sejalan dengan penelitian Syarniah et al (2014) bahwa masyarakat menganggap bahwa pasung adalah penanganan utama pada pasien ODGJ dan sebesar 55,1\% masyarakat mengatakan bahwa dilakukannyan pemasungan tersebut dikarenakan oleh alasan keamanan untuk pasien itu sendiri dan menghindari stigma yang negative dari masyarakat sekitar (Syarniah et al, 2014).

\section{Stigma Masyarakat}

Selain rendahnya pengetahuan keluarga, penerimaan masyarakat mengenai ODGJ juga belum baik. Masyarakat masih menganggap gangguan jiwa sebagai tabu dan merupakan sebuah aib sehingga mereka menutupi kondisi pasien. Mereka tidak memandang seperti penyakit lainnya yang dapat diobati.

Hasil wawancara dengan keluarga berikut ini:

"yo dio ni galak kabur ilang-ilang dari rumah, jadi aku kurung, dirante kakinyo dikamar ini lah biar dak ilang, tetanggo sini sering ngomongi, cuma aku nahan ati bae, malu sebenarnyo cuma nak cak mano lagi..." (NL)

Hasil wawancara dengan kader:

"ado keluargo yang nerimo, ado jugo yang tidak, keluargo malu dengan kondisi pasien..." (SP)

Hasil wawancara dengan Pengelola Program Puskesmas: "yo keluargonyo tu dek dak boleh tau kondisi pasien, ado pasien... kami disuruhnyo diam-diam jangan sampe tetanggonyo tau, dio malu, takut anaknyo diejek diomongi cak itu lah..." (SY).

Hasil penelitian menunjukkan bahwa stigma negative yang dimiliki masyarakat tersebut dapat mempengaruhi seluruh area kehidupan keluarga, menyebabkan isolasi secara fisik serta dapat membuat pasien sulit untuk mengaskes pelayanan kesehatan jiwa. Berdasarkan hasil wawancara dan observasi dengan keluarga pasien, bahwa penyuluhan ke masyarakat belum pernah dilakukan oleh pihak puskesmas terkait kesehatan jiwa ini.

Stigma negative terhadap pasien gangguan jiwa di Indonesia masih sangat tinggi yang dapat menyebabkan pasien ODGJ menjadi terkucilkan, diskriminatif dan dapat memperparah kondisi dari pasien tersebut (Wardhani \& Fauzia, 2014). Stigma negative merupakan salah satu hambatan yang dapat mencegah ODGJ mendapatkan perawatan yang tepat. Pada kenyataannya, 50-60\% ODGJ menghindari perawatan karena takut mendapat stigma yang negative. Tindakan menyembunyikan keadaan pasien merupakan salah satu tindakan yang dilakukan keluarga pertama kali yang 
dapat menyebabkan keterlambatan dalam pencarian pengobatan (Franz et al. 2010).

Hal tersebut sejalan dengan hasil penelitian bahwa keluarga malu dengan kondisi pasien dan menyembunyikan anggota keluarga yang sakit yang dapat memperparah kondisi pasien karena keterlambatan dalam pengobatan. Pengucilan terhadap keluarga maupun pasien akan terjadi dengan adanya stigma negative tersebut. Beban psikologi yang berat pada keluarga merupakan dampak dari stigma negative dari masyatakat yang berdampak pada kurang adekuatnya dukungan yang diberikan oleh keluarga pada proses pemulihan ODGJ.

Dukungan keluarga sangat dibutuhkan dalam proses pemulihan dan penyembuhan pada pasien. Kurangnya dukungan yang diberikan oleh keluarga yang menyebabkan keluarga melakukan tindakan pemasungan merupakan salah satu dampak dari stigma negative yang beredar di masyarakat (Nasriati, 2017). Kondisi tersebut berdampak pada buruknya dukungan emosional yang diberikan oleh keluarga. Dukungan emosional tersebut tidak akan diberikan keluarga kepada penderita (Friedman, 2010).

Upaya promotif merupakan salah satu tindakan yang harus dilakukan dalam mengatasi penghilangan stigma, meningkatkan derajat kesehatan jiwa masyarakat, diskriminasi, pelanggaran HAM, serta meningkatkan pemahaman, keterlibatan dan penerimaan masyarakat terhadap ODGJ. Bentuk upaya promotif tersebut antara lain yaitu dengan pemberian penyuluhan mengenai kesehatan jiwa dimasyarakat (Yusuf AH et al, 2019).

\section{Dukungan Ekonomi}

Tabel 2. Analisis Tema Dukungan Ekonomi

\begin{tabular}{lll}
\hline \multicolumn{1}{c}{ Tema } & \multicolumn{1}{c}{ Kategori } & \multicolumn{1}{c}{ Sub Kategori } \\
\hline $\begin{array}{l}\text { Pendapatan } \\
\text { masyarakat }\end{array}$ & Biaya & JKN yang tidak merata \\
yang tidak & pengobatan & $\begin{array}{l}\text { Bisa menggunakan KK } \\
\text { menentu }\end{array}$ \\
\hline
\end{tabular}

Program pengobatan dan perawatan kesehatan jiwa yang memerlukan waktu yang relative panjang menyebabkan terbebaninya kondisi psikologis keluarga. Kemajuan yang lambat dari setiap perkembangan pengobatan dari pasien ODGJ memberikan gambaran bagi keluarga bahwa ODGJ akan menjadi beban bagi keluarga baik secara psikologi maupun ekonomi. Faktor Ekonomi berkaitan dengan pemberian pelayanan kesehatan yang dibutuhkan. Biaya pengobatan, kesulitan ekonomi dan tidak adanya jaminan pembiayaan kesehatan merupakan sebagian penyebab kesenjangan pengobatan dari pasien ODGJ, karena itu penting menyediakan sistem asuransi kesehatan bagi ODGJ untuk mendukung akses ke pelayanan kesahatan jiwa.
Hasil wawancara dengan Pengelola Program Dinkes Kota Palembang:

"Itu salah satu masalah kita, masalah kita adalah JKN, jadi beberapa ODGJ kita ada beberapa yang belum punya JKN. Kemarin sudah kami dari petugas kesehatan kami usulkan ke Dinas Sosial, tapi sampai saat ini ada sekitar kurang lebih $320 \mathrm{KK}$ belum ada JKN, ODGJ itu belum ada JKNnya. Jadi, karena sekarang sistem rujukan ini berjenjang, jadi agak kesulitan kita itu salah satu hambatan kami juga. Jadi, dari puskesmas harus ke Tipe B dulu baru bisa ke RSJ Erba" (DK).

Hasil wawancara dengan keluarga pasien:

"dak tentu dek cukup makan bae, Alhamdulillah ado puskesmas dak bayar lagi tinggal ngasih KK biso konsul dan dapat obat langsung, BPJS sekarang lagi diurus" (PN).

Berdasarkan hasil penelitian diketahui bahwa pasien ODGJ rata-rata berasal dari keluarga dengan ekonomi rendah. Namun, dalam hal memanfaatkan pelayanan kesehatan jiwa di puskesmas, keluarga tidak mendapatkan kesulitan saat mengakses pelayanan tersebut di karenakan memiliki jaminan kesehatan. Dengan adanya jaminan kesehatan, keluarga pasien ODGJ sangat merasa terbantu dalam melakukan pengobatan dan pasien perlahan menunjukkan perkembangan kesehatan yang membaik serta dapat melakukan aktivitas sehari-hari berdampingan dengan keluarga atau masyarakat lainnya.

Pelayanan kesehatan yang terjangkau (affordable) oleh masyarakat merupakan salah satu syarat dalam penyediaan pelayanan kesehatan, biaya pelayanan kesehatan diharuskan sesuai dengan kondisi ekonomi masyarakat. Keterjangkauan dalam biaya pelayanan dapat memudahkan setiap orang memelihara kesehatannya secara berkesinambungan (Kemenkes, 2015).

Faktor penghasilan juga mempengaruhi dukungan buruk yang diberikan oleh keluarga terhadap pasien ODGJ. Ketersediaan fasilitas kesehatan yang diperlukan dapat ditentukan dari status ekonomi masyarakat tersebut, sehingga status sosial ekonomi ini akan mempengaruhi dukungan seseorang (Hawari \& Dadang, 2011). Ching et al (2016), menyebutkan bahwa faktor yang mempengaruhi dukungan salah satunya faktor sosio ekonomi yakni semakin tinggi tingkat ekonomi seseorang biasanya akan lebih cepat tanggap terhadap gejala penyakit yang dirasakan. Salah satu wujud dari dukungan instrumental yang akan digunakan dalam mencari pelayanan kesehatan jiwa dalam merawat anggota keluarga yang mengalami gangguan jiwa adalah penghasilan keluarga (Ching Wu.H, Chen.F, 2016).

Mancini (2017) menyatakan bahwa faktor yang berperan terhadap rendahnya beban keluarga adalah fasilitas jaminan kesehatan. Penghasilan yang rendah akan menimbulkan beban yang berat dalam merawat 
ODGJ, namun hal itu tidak membuat keluarga merasa sangat terbebani karena keluarga memiliki fasilitas jaminan kesehatan yang sangat menopang financial caregiver, sehingga akan mengurangi beban perawatan (Mancini, 2017).

Aspek pembiayaan kesehatan jiwa didapatkan adanya dukungan pemerintah untuk menerapkan Jaminan Kesehatan Nasional (JKN) dalam layanan kesehatan termasuk kesehatan jiwa dalam mencapai Universal Coverage pada tahun 2019 ini. Hal ini merupakan potensi cukup besar untuk menjamin ODGJ dalam mendapatkan pelayanan kesehatan yang dibutuhkan dan meningkatkan cakupan pelayanan kesehata jiwa. Sejumlah penelitian menemukan bahwa dengan adanya puskesmas sebagai layanan kesehatan dasar sangat membantu dalam perawatan dan kesembuhan pasien ODGJ yang dapat meningkatkan kesejahteraan psikologis pasien serta Jaminan Kesehatan tersebut dapat memperluas akses masyarakat ke pelayanan kesehatan jiwa (Pratiwi et al, 2015).

\section{Identifikasi A wal}

Pelaksanakan kesehatan jiwa yang ada pada lingkungan masyarakat pengguna ini mulanya dilakukan dengan kegiatan identifikasi awal oleh kader jiwa yang bertugas. Kader jiwa memiliki tugas yang dapat dikatakan lebih kompleks dibandingkan dengan pemangku kepentingan lainnya.

Tabel 3. Analisis Tema Identifikasi Awal

\begin{tabular}{lllr}
\multicolumn{1}{c}{ Tema } & Kategori & \multicolumn{2}{c}{ Sub Kategori } \\
\hline Pentingnya & Penjaringan & Susah & mendapat \\
pemberdayaan & Kasus & laporan & dari \\
masyarakat & & masyarakat & \\
& & Keluarga & tidak \\
& & terbuka & \\
& & Sering & terjadi \\
& & penolakan & dari \\
& & pihak keluarga \\
\hline
\end{tabular}

Hasil wawancara dengan kader:

“...dari tetanggo dan dari lingkungan tempat kami tugas sebagai kader bahwa disana ada kasus odgj, jadi kita datangi, kita crosscheck dan kemudian kita lapor pihak puskes...kasus yang sudah saya di temukan itu sekitar 10 ya" (RD)

Hasil wawancara dengan Pengelola Program Puskesmas: "waktunyo itu sebenarnyo susah, paling kadang kito dapat laporan dari kader itu lah, kalo kader sudah laporan agek tinggal atur waktu untuk kunjungan, atau pasiennyo itu dewek yang langsung berobat kesni kan..." (RS)

Hasil wawancara dengan Dokter:

"dalam penjaringan kasus kita mendapatkan laporan dari kader, RT, lurah, camat dan lainnyo, nah kalo sudah dapat laporan baru kito adakan kunjungan rumah itu, kito crosscheck...paling banyak laporan dari kader karna kan emang tugasnya kader dalam penjaringan dan pelaporan kasus untuk membantu kita" (PD)

Hasil wawancara dengan Pengelola Program Dinkes Kota :

"pemberdayaan masyarakat itu penting ya untuk membantu puskesmas terutama dalam penemuan kasus itu, namun ya itu tadi masih ada puskes yang belum ada kader ...”(DK).

Berdasarkan hasil penelitian diketahui bahwa dalam melakukan identifikasi awal kader jiwa melakukan beberapa proses mulai dari mengetahui dan melihat secara langsung terhadap ciri-ciri yang dimiliki oleh individu tersebut, atau mendapat laporan dari beberapa masyarakat lain mengenai tingkah laku individu yang diyakini sebagai penderita gangguan jiwa. Setelah itu proses identifikasi dilanjutkan dengan adanya tindakan mendatangi keluarga pasien dan dilakukannya sosialisasi secara mendasar. Kader juga memberikan edukasi/sosialisasi mengenai layanan kesehatan jiwa dan memberi informasi kepada keluarga terkait penanganan pasien serta kader akan melaporkan kasus tersebut ke bagian pihak puskesmas untuk ditanggulangi.

Hasil wawancara diketahui bahwa 1 kader bisa menemukan 3-5 kasus ODGJ di wilayah kerja puskesmas masing-masing. Kader dapat dengan mudah menemukan kasus karena merupakan masyarakat/tetangga sekitar sehingga kader bisa dengan mudah melakukan pendekatan ke keluarga pasien. Akan tetapi, berdasarkan hasil observasi kader kesehatan jiwa tersebut belum mendapatkan pelatihan secara menyeluruh.

Identifikasi awal merupakan kegiatan penjaringan kasus-kasus gangguan jiwa yang dilaksanakan secara terencana, komprehensif dan multidisipliner difasilitasi oleh manajer kasus dengan berfokus kebutuhan individu (Yusuf AH et al, 2019). Profesi atau petugas yang bisa menjadi menejer kasus dilingkungan masyarakat ini adalah pekerja sosial, kader kesehatan jiwa yang terlatih dan juru latih (terapis) kerja (Kemenkes, 2010).

Hasil penelitian menunjukkan bahwa Kader memiliki tugas yang dapat dikatakan lebih kompleks dibandingkan dengan pemangku kepentingan lainnya. Tugas utama dari kader yaitu melakukan identifikasi kasus-kasus orang dengan gangguan jiwa, yang nantinya akan ditindaklanjuti oleh pihak puskesmas. Akan tetapi, beberapa puskesmas tidak memiliki kader kesehatan jiwa yang menyebabkan kesulitan dalam penjaringan dari kasus gangguan jiwa.

Keberhasilan perawatan selanjutnya terhadap pasien ODGJ yaitu kemampuan kader dalam menemukan secara dini penderita gangguan jiwa dimasyarakat (Sutarjo et al, 2016). Kunjungan rumah merupakan langkah identifikasi awal yang dilakukan oleh kader dan cara tersebut efektif untuk 
menyampaikan informasi. Beberapa keluarga ODGJ pada awalnya belum mengatahui jika ada pelayanan kesehatan jiwa ada di puskesmas, Adanya informasi yang disampaikan kader, memberikan efek positif kepada keluarga ODGJ dikarenakan keluarga menjadi tahu mengenai adanya pelayanan kesehatan jiwa di puskesmas sehingga keluarga dapat dengan mudah mengakses pelayanan kesehatan jiwa tersebut (Surahmiyati et al, 2017).

Penelitian yang dilakukan oleh Hanifah et al (2017) menunjukkan bahwa kader dapat menjaring atau menemukan kasus dengan mudah dikarenakan kader merupakan bagian dari masyarakat. Kader dalam melakukan identifikasi awal dengan menggunakan pendekatan-pendekatan tertentu dengan keluarga ODGJ. Hal tersebut sejalan dengan penelitian ini bahwa puskesmas yang memiliki kader mengalami peningkatan penemuan jumlah kasus ODGJ dibandingkan dengan puskesmas yang tidak memiliki kader kesehatan jiwa (Hanifah \& Afridah, 2018).

Kader berpotensi mempengaruhi dan merubah keyakinan atau persepsi masyarakat mengenai gangguan jiwa. Kader tidak mengalami hambatan jarak, budaya, bahasa, agama dan status sosial untuk berkomunikasi dan membangun hubungan kepada pasien maupun keluarga pasien ODGJ (Kemenkes, 2014). Perlibatan/pemberdayaan masyarakat merupakan langkah efektif untuk mengatasi masalah kesenjangan pelayanan kesehatan jiwa. Peran kader menjadi bukti potensi sumber daya masyarakat yang dapat dioptimalkan untuk meningkatkan kualitas hidup ODGJ dan keluarganya. Hal ini sejalan dengan penelitian di Kenya bahwa Pekerja Kesehatan Masyarakat melakukan peran penting sebagai pendidik kesehatan dan dapat meningkatkan pengetahuan masyarakat, kemudahan pengobatan pasien dan sosialisasi dengan masyarakat sekitar mengenai kesehatan jiwa (Pratiwi et al, 2015). Maka dari itu sangat dibutuhkannya pemberdayaan masyarakat dalam pelayanan kesehatan jiwa.

\section{SIMPULAN}

Kurangnya kesadaran masyarakat dalam pencarian pengobatan dan penanganan pasien ODGJ dikarenakan rendahnya pengetahuan dan tingginya stigma negatif yang ada dimasyarakat. Hal tersebut dapat berdampak pada dukungan yang diberikan oleh keluarga. Maka sangat diperlukannya upaya promotif dalam upaya kesehatan berbasis komunitas seperti penyuluhan dan edukasi serta pemberdayaan masyarakat sebagai perpanjangtangan dari puskesmas dalam menjangkau masyarakat untuk mengakses pelayanan kesehatan jiwa secara luas.

\section{DAFTAR PUSTAKA}

Ching Wu.H, Chen.F. 2016. Sosiocultural Factors Associated with Caregiver-Psychiatrist Relationship in Taiwan Psychiatry Investig.
Pskiatri Investig. 13

http://www.ncbi.nlm.nih.gov.

(3): $\quad 288-296$.

Dinas Kesehatan Kota Palembang. 2017. Profil Kesehatan Kota Palembang. Sumatera Selatan.

Direktorat Bina Kesehatan Jiwa Kementerian Kesehatan Republik Indonesia .2015. Mental Health.

Franz. L, Carter T, Leiner A.S, Bergner.E. 2010. Stigma and Treatment Delay in First-episode Psychosis: A Grounded Theory Studi. Early Interv Psychiatry. $\quad 4(1): 47-56$. http://www.ncbi.nlm.nih.gov

Friedman, M. 2010. Keperawatan Keluarga Teori dan Praktek. Ed 3. Jakarta: ECG.

Hanifah AN, Afridah W. 2018. Upaya Mengoptimalkan Pelayanan Kesehatan Jiwa Berbasis Masyarakat di Kelurahan Wonokromo Surabaya. Jurnal Universitas Nahdlatul Ulama Surabaya.

Hawari, Dadang. 2011. Manajemen Stress Cemas dan Depresi. Jakarta: Balai Penerbit FK UI.

Jordans MJD, Luitel NP, Kohrt BA, Rathod SD, Garman EC, De Silva M, Komproe IH, Patel Ikram, Lund Crick. 2019. Community-, facility-, and individual-level outcomesof a district mental health care plan in a low-resource setting in Nepal: A population-based evaluation. PLoSMed 16(2):

e1002748.https://doi. org/10.1371/journal.pmed.1002748.

Keliat, B.A, Riasmiani M and Daulima N.H.C, 2012. The Effetivness of the Implementation of Community Mental Health Nursing model Toward the Life Skill of Patiens with Mental Disorder and their Family in Jakarta. Depok: Directorate of Reasearch and Public Service Universitas Indonesia.

Kemenkes. Rencana Strategis Kementerian Kesehatan Tahun 2015-2019. Jakarta: Kementerian Kesehatan RI; 2015.

Kementerian Kesehatan RI. 2010. Buku Pedoman Pelayanan Kesehatan Jiwa di Fasilitas Pelayanan Kesehatan Dasar. Jakarta.

Kementrian Kesehatan RI. 2014. Undang Undang No 18 Tahun 2014 Tentang Kesehatan Jiwa. Lembaran Negara RI tahun 2014 No.5571. Jakarta : Sekretariat Negara.

Keynejad RC, Dua T, Barbui C, Thornicroft G. 2017. WHO Mental Health Gap Action Programme (mhGAP) intervention guide: a systematic review of evidence from low and middle-income countries. Evid Based Ment Health. 21(1):30-4. https://doi.org/10.1136/eb-2017-102750 PMID: 28903977.

Lestari Wardhani \& Fauzia Y. 2014. Stigma dan Penanganan Gangguan Jiwa Berat yang di Pasung. Buletin Penelitian Sistem Kesehatan. Vol 7 No 2. 157-166.

Mancini, M.A 2017. An Exploration of Factors that Efeect the Implementation of Peer Support Services in Community Mental Health Settings. 
Community Mental Health Journal. Springer US. 0(0). p.0. doi: 10.1007/s10597-017-0145-4.

Nasriati R. 2017. Stigma dan Dukungan Keluarga dalam Merawat Orang Dengan Gangguan Jiwa (ODGJ). Medisains Jurnal Ilmiah Ilmu-Ilmu Kesehatan. Vol. 15 No. 1.

Pratiwi A, Muhlisin A, Sudaryono A, Kurniwan ST. 2015. Penyakit Jiwa di Komunitas. Jurnal Warta Fakultas Ilmu Kesehatan Universitas Muhammadiyah Surakarta. Vol 28 No 2. ISSN 1410-9344.

Rosiana A, Yuli Setyaningrum, N.A. 2016. Ipteks Bagi Masyarakat (Ibm) Kelompok Kader Kesehatan Jiwa di Desa Pasuruhan Kidul Kabupaten Kudus dalam Upaya Pemberdayaan Kader Kesehatan Jiwa untuk Meningkatkan Kemandirian dengan Metode "One Volunter One Patient". The $4^{\text {th }}$ University Research Coloqu, 458-465.

Subandi. 2012. Dimensi Keluarga Pasien Psikotik di Jawa. Jurnal Psikologi, Universitas Gadjah Mada Vol 35 No 1: 62-79.

Surahmiyati S, Yoga BH, Hasanbasri M. 2017. Dukungan sosial untuk orang dengan gangguan jiwa di daerah miskin: studi di sebuah wilayah puskesmas di Gunungkidul. BKM Journal of Community Medicine and Public Health. Vol 33 No 8.

Suswinarto DY, Andarini Sri, Lestari Reno. 2015. Studi Fenomenologi : Pengalaman Keluarga Terhadap Pemasungan dan Lepas Pasung pada Anggota Keluarga yang Mengalami Gangguan Jiwa Berat di Wilayah Kerja Puskesmas Bantur Kabupaten Malang Propinsi Jawa Timur. Jurnal Ners dan Kebidanan. Vol 2 No 2.

Sutarjo, P., Pamungkas, D.R., Linawati, O.M. 2016. Stigma Terhadap Orang dengan Gangguan Jiwa (ODGJ) Pada Mahasiswa Program Studi Ilmu Stikes Jenderal Achmad Yani Yogyakarta. Media Ilmu Kesehatan. 5(2), 128-132

Syarniah, Rizani A, Sirah E. 2014. Studi Deskriptif Persepsi Masyarakat Tentang Pasung Pada Klien Gangguan Jiwa Berdasarkan Karakteristik Demografi di desa Sungai Arpat Kecamatan Karang Intan Kabupaten Banjar. Jurnal Skala Kesehatan. Vol 5 No 2.

Tristiana RD, Yusuf A, Fitryasari R, Wahyuni SD, Nihayati HE. 2018. Perceived Barries on Mental Health Services by The Family of Patients with Mental Ilness. International Journal of Nursing Sciences. 5(1):63-7.

World Health Organization. The World Medicine Situation 2011 3ed. Rational Use of Medicine. Geneva, 2011.

Yusuf AH, Fitryasari R, Nihayati NE, Tristiana RD. 2019. Kesehatan Jiwa (Pendekatan Holistik dalam Asuhan Keperawatan). Edisi Pertama. Jakarta : Mitra Wacana Media. 